\title{
Assessment of the Adoption and Implementation of IFRS for Small and Medium Scale Entities (SMEs). "A Study of Selected SMEs GA East of Ghana"
}

\author{
John Kwaku Mensah Mawutor \\ Dean, School of Graduate Studies (SOGS) \\ University of Professional Studies, Accra Ghana \\ P.O. Box LG 149, Legon \\ Tel: 23-32-4328-7242Ｅ-mail: john.mensah@upsamail.edu.gh / \\ kwaku2mensah@gmail.com \\ Siaw Wlliams \\ University of Professional Studies, Accra (UPSA), Ghana \\ Mensah Anita Oduwaa \\ University of Professional Studies, Accra (UPSA), Ghana
}

Received: April 17, 2019 Accepted: June 5, $2019 \quad$ Published: June 1, 2019

doi:10.5296/ajfa.v11i1.14678 URL: https://doi.org/10.5296/ajfa.v11i1.14678

\begin{abstract}
The IFRS for SMEs is an important element for attaining competitive advantage, attracting investors and gaining access to financial assistance in today's world of competitive business irrespective of their size. The study assessed the adoption and implementation challenges of IFRS for SMEs among SMES in GA East (Madina). To assess the adoption and implementation benefits and challenges, a qualitative research and conceptual and theoretical framework was developed. These guided the design of the data collection instrument to suit the research. The study collected primary data by conducting interviews on 20 respondents. Purposive sampling techniques were used to select the firms. Data collected as transcribed and coded into the Nvivo software. The study revealed that, about $60 \%$ of Small and medium entities in Madina do not have knowledge about the IFRS for SMEs. The study further revealed that meeting regulatory
\end{abstract}


requirements and avoiding noncompliance cost were some of the factors that necessitated firms with little knowledge on the standard to adopt it.

Keywords: IFRS, SMEs, GA Est, Ghana, Adoption, Implementation, Regulatory, Noncompliance 


\section{Introduction}

In recent times, the rate at which economies and businesses engage in international trade has significantly increased. For this reason, investors, financiers, business partners and decision makers who are comfortable with the international standard, s may not find financial statements prepared in accordance to the local generally accepted accounting principle (GAAP) useful (Gyasi, 2010). Titilayo, Folashade and Ifeoma (2014), stated in their study that, highly accepted measuring stick dialect of accounting should be used by Small and Medium Sized Entities (SMEs) in conveying their accounting results to their stakeholders and the intention was to make likeness in every business view point as globalization is on the rise. This practice will make SMEs' financial statement reliable and simple to understand. According to the International Accounting Standards Board (IASB) (2009), Small and Medium-Sized entities are the principal groups of entities (public or local) with about $95 \%$ composition on the international market. Therefore, their contribution towards economic growth, exportation and revenue generation (taxation), and unemployment reduction, cannot be over emphasized particularly in developing countries (Amoako G. , 2013).

Despite their contributions and size on the market, study shows that about $60 \%$ of SMEs become unsuccessful within their first five years in business and this was very alarming (Boachie-Mensah \& Marfo-Yiadom, 2005). Some of the reasons were the lack of requisite skills needed to, ability to ensure and sustain growth, leverage on technological advancement and the efficient use of human resources in order to sharpen its competitive advantage with the major reason being the ability to secure and mobilize finances (Williams, Haka, Bettner, \& Carcello, 2008). As an emerging country, Ghana needs high-quality financial information to access international financing resources (Alp \& Ustundag, 2009). There was therefore the need for SMEs in Ghana to discontinue with local standards for reporting purposes with reason being that, most national standards do not give a satisfactory level of comparability (Wyk \& Rossouw, 2009). As a result of the synchronization of accounting practices, the adoption of International Financial Reporting Standards (IFRS) has increased significantly and this has led to many nations adopting it. However, the full IFRS publicized by the IASB, has been found to be irrelevant due to the disclosure requirements which are too extensive for SMEs (Titilayo, Folashade \& Ifeoma, 2014). These necessitated the IASB to issue the IFRS for SMEs in July 2009. According to Albu and Albu (2012), addressing the need for international comparability in terms of financial reporting by SMEs was the main intention of the IASB for the introduction of IFRS for SMEs. This research was therefore motivated and carried out to analyze the adoption and implementation of IFRS for SMEs in Madina. The main objective of the study was to analyze the adoption and implementation of IFRS for SMEs in Greater Accra East (GA East).

\section{Literature Review}

According to Pricewater house coopers (2009), the term small and medium-sized entities (SMEs) have different meanings in various territories. Many authors argued that the concept of SME is too broad and abstract; therefore, it differs from country to country as well as entities to entities. However, Ward (2018) mentioned that, what exactly an SME or Small to Medium 
Entity is, depends on who is doing the defining. Depending on the country, the size of the entity can be classified based on its number of employees, annual sales, assets, or any combination of these (World Bank, 2017). It may also differ across industries. Hence, there is no specific definition of SMEs due to the changing rates of improvement.

In the European Commission attempt to define SMEs, they gave three distinctive classifications of SMEs. The biggest classification was the medium-sized enterprises which comprises entities that employ less than 250 staffs with a yearly revenue of less than or equal to 50 million Euros and an annual statement of financial position total of less than or equal to 43 million Euros. In continuation, they defined small enterprises as enterprises which engage less than 50 employees and their annual gross revenue or statement of financial position aggregate does not go beyond 10 million Euros. Lastly, micro-enterprises were referred to as enterprises which employ less than 10 employees and whose yearly revenue or statement of financial position aggregate does not go beyond 2 million Euros. They however maintained that, the employee headcount threshold is obligatory; nevertheless it is not compulsory to meet both revenue and statement of financial position thresholds simultaneously (Mandilas, Nikolaidis, \& Stavros, 2015).

IASB (2009), also defined small and medium-sized entities as entities that do not have public accountability and issue general purpose financial statements to its users. The IASB (2009), further mentioned examples of these external users to include owners who are not involved in managing the business, existing and potential creditors, and credit rating agencies (O'Dell, 2008). According to IASB (2009), "an entity has public accountability if its debt or equity instruments are traded in a public market or it is in the process of issuing such instruments for trading in a public market (a domestic or foreign stock exchange or an over-the-counter market, including local and regional markets) or it holds assets in a fiduciary capacity for a broad group of outsiders as one of its primary businesses (most banks, credit unions, insurance companies, securities brokers/dealers, mutual funds and investment banks would meet this second criterion)".

For the purpose of this study, the Institutional Theory (IT) was reviewed. According Scot (2004), the Institutional theory is a broadly accepted theory that highlights cogent isomorphism and legality. Institutional theory ponders on the procedures by which structures, methods, customs and practices produce persuasive procedures for social conduct by centering on the robust and deeper aspects of social structure. Different components of institutional theory expound how these fundamentals are formed, adopted and adapted over time. Institutional theory has been noted to be a treasured tool in identifying the drivers of IFRS for SMEs adoption. Institutions are defined as social structures that have become resilient and robust (Scott R. , 1995). Institutions can also be said to constitute regulative fundamentals, resources and other related activities that provide stability and meaning to life (Scott R. , 1995). Nevertheless, there exists no precise and generally accepted meaning of an "institution" in the institutional viewpoint.

It is fascinating to note that, a supporting reason for the increasing resemblance in organizational systems and practices across the world is that, institutional isomorphic pressures 
have been the drivers pushing organizations with increasingly comparable characteristics to adopt policies that reflect their social position. The three forms of isomorphism contained by the new institutional theory were recognized by Dimaggio and Powell (1991). The first form is coercive isomorphism which emanated from political influence and the problem of legality, the second type recognized is mimetic which results from replies to principles that face uncertainty then the last which is normative is allied to professionalism. A critical examination of these forms of institutional pressures following the adoption of IFRS for SMEs in African countries offers great opportunities to clarify the institutional conditions that drive the policy adoption decisions. An extensive discussion and the context within which each form of institutional pressures involved in policy resolution is provided.

Coercive Isomorphism rooted from political influence in addition to legality problems. Following this reason, the existence or nonexistence of institutions that can inspire economic players to adapt to international accounting standards could be one of the key prime movers of international accounting standards acceptance (Judge, Li, \& Pinsker, 2010). This form of isomorphism might instigate from all circles of the environment in which an organization operates, be it structural or political. It assumes the form of a stringent or easy-going pressure put forth on an institution by other bigger institutions upon which they are governed or the social setting within which an organization function. This refers to the manipulation of incentives by powerful factors to encourage others to implement policy changes (Simmons, Hamann, Harenski, Xiaoping, \& Barsalou, 2008). The Securities and Exchange Commission regulates institutions whose shares are openly traded under the Securities Industry Law (1993) and Securities and Exchange Commission Regulations (2003) while the Ghana Stock Exchange regulates listed entities under the Stock Exchange Act (1971) and the Listing Regulations (Worldbank, 2004).

Unlike the coercive which emanates from political influence and legitimacy. Imitations have been prevented by the powerful force of uncertainty. Effective as well as authentic organizations are imitated by other comparable organizations in their field of operation. Therefore successful international businesses that originate from overseas locations are to be expected to toe the line of IFRS and local players possibly will duplicate these successful international businesses (El-Gazzar, Sawn, Finn, P, \& Jacob, 1999). Also the inflow of Foreign Direct Investment (FDI) has been a major factor influencing the international standards that are of quality within a country (Guler, Guillen, \& Macpherson, 2002)country. Guler, Guillen and Macpherson (2002) articulated that, the inflow of Foreign Direct Investment (FDI) has paved way for more economic cohesiveness and has therefore empowered local executives and residents to follow what they regarded as worthwhile of being a participant of the comprehensive marketplace. The World Bank noted that there were serious discrepancies with respect to compliance to the Generally Accepted Accounting Principles (GAAP) of Ghana. That is, the Institute of Chartered Accountants of Ghana (ICAG) has not updated any national standards since they were originally adapted from international standards (Estandardsforum, 2009). The aforementioned also recognized that the Ghana National Accounting Standards contained twenty eight (28) standards and withdrawn from the standards was its international equivalents of certain Ghana National Accounting Standards, while ten active international 
standards were not reflecting in the Ghana National Accounting Standards as at the time of the 2004 report of the World Bank. Also, standard number forty-one (41) of the International Accounting Standards significant to Agriculture was noticed to have been excluded from the Ghana National Accounting Standards.

Due to the above-mentioned gaps coupled with others generated uncertainty in the accounting profession. International Financial Reporting Standards (IFRS) adoption turns out to be of utmost importance in identifying a remedy for these gaps. Normative isomorphism was the last application of isomorphism within institutional theory and this is ascribed to professionalization. The role of Professionals in the formulation and advisory aspects of policy across all fields is very critical. While professionals strive to adhere to strict codes of ethics and professional practice guidance, they turn to form a social group who exchange ideas relating to their professional domain. Dimaggio and Powell (1991) argue that, shared principles that result in following the line of accomplishment and thought within institutional setting emerge from this form. Guler, Guillen and Macpherson (2002) predict that, the degree of professional technical knowledge of a nation has a positive relationship with its ability to adapt to standards that are of good quality and internationally recognized which were facilitated by professional standards. Therefore, a Nation 's attainment of education may spark normative pressures birthed by professionalism.

\subsection{Empirical Literature}

Amoako, (2013) conducted a quantitative study which employed a sample size of 210 SMEs in the Kumasi metropolis and obtained data through questionnaires. The findings of the study established that the owners who are mostly the managers believes that if they prepare financial statements, the real worth of their businesses would be exposed which they perceived as harmful to the image of their firms. He also found out in his study that most SMEs in Ghana that prepare financial statements only do so for tax purposes and not because they wish to. In addition (Ialin \& Irfan, 2010); (Ezejiofor, Ezenyirimba, \& Olise, 2014) are also of the opinion that the main reasons SMEs prepare financial statements was pressure from regulatory authorities. They conducted a quantitative study where 250 questionnaires were distributed to SMEs to obtain data. Maseko \& Manyani, (2011) also conducted a quantitative research where structured questionnaires were used to extract primary data from the respondents. Their study focused on accounting records keeping practices and found out in their study that, majority of SMEs do not keep complete accounting records because of lack of accounting knowledge and inefficient use of accounting information in managing financial performance. They mentioned again in the study that, SMEs concern of keeping incomplete accounting records in developed and developing economies has been in existence not now but for a longer time and has therefore been drawn towards the attention of researchers, Professional Accounting Bodies, Professional Accountants, Economists, Investors, Policy makers and Financial Institutions.

The Report on the Observance of Standards and Codes (ROSC, 2004) also revealed that Ghana has weak institutional capacity as well as regulatory framework, weak compliance and enforcement of standards and rules leading to poor accounting by companies operating in the country. The report further argued that most institutions that claim to be preparing financial 
statements were either having incomplete records or their standards of reporting were poor irrespective of the standard they were using. Hence, most SMEs in the country do not keep proper record of their transactions. Scott and Des (2012) concluded in their study that, the volume of accounting practices in SMEs depends on several operating environmental factors that include size of the business, business age and industrial grouping. They further argue that most owners and managers of SMEs engage public accountants to prepare required information and that they search for additional information, but only to a limited extent.

\section{Methodology}

With a sample size of twenty (20) from SMEs based in the GA East of the Greater Accra Region of Ghana, a qualitative research approach was adopted to describe the target population in an accurate way. Survey method which a type of is (Abata, 2015) descriptive method was employed where the participants were asked to answer questions through interviews. Non probability sampling technique was employed since the selection of the SMEs was based on the researcher's judgment thus, not all SMEs have equal chances to be selected. This helped to ascertain accurate information to draw conclusions for decision making. Purposive sampling method was employed by the researchers as used by (Sithole, 2015) in a similar research. Purposive sampling technique was employed by the researchers because; SMEs that best suits their study who were willing and able to answer their questions in order to meet the objective of the study were selected.

Primary and secondary data was used in this study through a structured interview employed to solicit information from respondents. The interview questions had three major chapters. The first part covered the demographic profile of the respondents followed by the profile of the business entity. The next chapter focused on the questions that the researchers sought to ascertain from the respondents, their knowledge of the introduction of IFRS for SMEs followed by the extent of their adoption and implementation of the standard. Finally, respondents were provided a space to list both perceived and actual benefits as well as challenges that are associated to the adoption and implementation of the IFRS for SMEs.

To analyze data collected, the Content Analysis (Thematic) technique was employed to comprehend the total themes that arises in qualitative data. Using techniques like colorful coding specific themes and ideas helps analyze recorded data to find the most common responses. The study employed the content analyses in drawing conclusions since our data collection techniques are such as interview data and open-ended surveys. For the analysis, The Nvivo software was used in the processing of the raw data as used in similar qualitative research by Betul (2004) where Nvivo was used to analyze the data and outlines the methodology that was adopted in their study. All necessary analysis was made from the output of the Nvivo.

\subsection{Analysis and Discussion of Findings}

\section{Description of the results}


Table 1. Genders of Respondents

\begin{tabular}{llll}
\hline SEX & Frequency & Cumulative Frequency & Percentage (\%) \\
\hline Male & 14 & 14 & 70 \\
Female & 6 & 20 & 30 \\
Total & 20 & 20 & 100 \\
\hline
\end{tabular}

Source: Survey data, 2019.

From the table, the representative of the firms who we interviewed as our respondents had males representing $70 \%$ of the sample size while $30 \%$ were females. Although, there is a gender imbalance in our respondents the responses from all these respondents gives the actual happenings of every firm. This presupposes that males are more inclined in the implementation of the standard as compared to females.

Table 2.

\begin{tabular}{lllll}
\hline $\begin{array}{l}\text { LEGAL STATUS } \\
\text { OF } \\
\text { RESPONDENT }\end{array}$ & $\begin{array}{l}\text { NUMBE } \\
\text { OF FIRMS }\end{array}$ & PERCENTAGE & $\begin{array}{l}\text { ADOPTED } \\
\text { THE IFRS }\end{array}$ & PERCENTAGE \\
FIRMS & & & FOR SMES & \\
\hline $\begin{array}{l}\text { Privately owned } \\
\text { companies }\end{array}$ & 6 & $30 \%$ & 6 & $30 \%$ \\
$\begin{array}{l}\text { Partnerships } \\
\begin{array}{l}\text { Sole- } \\
\text { Proprietorship }\end{array}\end{array}$ & 5 & $25 \%$ & 2 & $10 \%$ \\
\hline
\end{tabular}

Source: Survey data, 2019.

From the above table, twenty (20) respondents were interviewed out of which six (6) were registered privately owned companies and all these firms had adopted and implemented the standard taking between 6 months to 2 years in their implementation processes. Five (5) out of the twenty (20) were partnership firms with only two (2) implementing the standard. None of the nine (9) respondents who were operating sole proprietorship business had any basic knowledge in the standard with just a handful declaring hearing the name a few times but had no knowledge of what it meant. From the table, the eight (8) firms that had adopted the standard were bigger in terms of size and structures and were well established, with a few having branches. This supports the claim by Aboagye-Okyere \& Agbeibor (2012) who in their study noted that, the standard to a significant extent is biased towards firms that are well structured. This poses a question as to whether the size and structure of these SMEs were considered by the IASB when designing the standard.

\section{Discussion of Results}

The awareness level of and the key motivators for the adoption, of the IFRS for SMEs. 
The IFRS for SMEs, was initially introduced in July 2009, and finally adopted by Ghana in 2012 by the institute of chartered accountants Ghana. It is however surprising that, $60 \%$ of the total firms interviewed in Madina, said they had no knowledge of the said standard.

"Our business is not aware of any thing called IFRS for SMEs; can you tell us about it? IFRSforSMEsR6. We don't have any idea on what the standard is although we have heard of it IFRSforSMESR11. These responses show that, firms have no knowledge of the fact that a standard has been adopted on their behalf which is expected to solve their challenges as firms. This challenge was also identified by Arhin, Perprem, \& Hulede (2017) in their study into challenges of adopting and implementing IFRS for SMEs in Kumasi who argued that, most SMEs have no idea of the IFRS for SMEs and added that regulatory bodies should devise means to create awareness on the said standard.

"I am not aware of any standard like IFRS for SMEs. I do not make any good sales apart from orders from partners to supply and so we using this standard will only be a burden" IFRSforSMESR1. Owners of sole proprietorship business chorused similar response that, they did not know anything regarding the standard being referred to, by the researchers. To the few who did not keep proper records, the standard will only put unnecessary responsibilities on them of which they are not prepared for.

"The business is small and cannot adopt any standard; we are used to our normal way just for tax purposes". Upon providing a few insights into the standard to these entities, the researchers realized that these firms have little or no interest in whatever the standard had for them and as such were not prepared to learn anything about the said standard. There is a great need to commence an awareness campaign to educate SMEs about the need to adopt this standard. Kilic \& Ataman (2016) in a similar study also revealed that $50 \%$ of their total respondents had moderate knowledge while $30 \%$ had little or no knowledge about the standard. One can infer that, an awareness campaign is generally needed in all the countries that have adopted the standard.

\section{The benefits to be derived from the successful implementation of the IFRS for SMEs}

The introduction of the IFRS for SMEs by the IASB had with it good reasons to improve the financial reporting framework of firms specifically SMEs. According to Zegal, yosra, \& Sondra, (2011) the adoption of the standard can advance the quality of a firms financial reporting. The standard from its inception promised, among other things, easy understandability, comparability and the like.

Despite the numerous challenges stated by the respondents, a few of them spoke of certain benefits they enjoyed in the implementation of the standard.

"since we always had our financial statements prepared in our own way without any specific format but only ensured that we capture all our expenses as well as our revenues, we always found it difficult to get access to credit but upon adopting the standard, it has helped us gain financial assistance from banks through the preparation of a good financial statement" IFRSforSMEsR5. Two respondents believed that, there is a positive relationship between quality financial statement and access to credit and therefore the successful implementation of 
the IFRS for SMEs should also help other firms in the quest to secure financial assistance. This supports the argument by (Rudzani \& Charles, 2016) that firms get easy access to loans when they can present financial statements that are acceptable by banks for their assessment before granting loans.

"I had some business partners who wanted to invest in my business but they were not comfortable with how I prepare my financial statement but when I started using this standard, I have had three business partners investing in my business and in my view I think there might other future benefits which I am yet to enjoy with the passage of time IFRSforSMESR20. This tells that investor confidence in firms' financial statement is paramount when it comes to choosing a company for investment. This supports the argument by The IASB 2009 that, if capital providers do not understand or have confidence in the financial information they receive, an SME's access to, and cost of capital will suffer.

"Now that we can clearly identify our capital expenses from the revenue types, we now get a true reflection of our profit for the period end. The business is now able to clearly assess its financial performance for the period and make the necessary decisions. This will also help us to state the correct tax amount for every period easily" IFRSforSMESR13.

Quiet an appreciable number of SMEs asserted that they had no benefit locally from the implementation of the standard. "We are not getting any benefit from the use of the standard so if it comes to benefits what we can lay hand on is the knowledge that we are complying with regulatory requirement and avoiding any penalty from noncompliance".

"Although we are using the standard, we have not had anything to do with international credit facilities or any international investment from and a foreign investor but we have had benefits within the country" IFRSforSMESR17 "Although we have international investors, it was not as a result of the IFRS for SMEs adoption that they invested in this company. This is because we had them as investors because they are relatives and they also invested into the company before we adopted and implemented the standard IFRSforSMEsR3.

None of the responses showed that, any firm has had any international benefit. These raises the question as to whether SMEs in Madina and by extension the country Ghana has had more benefits than challenges from the adoption and implementation of the IFRS for SMEs. A similar study conducted at Kumasi one of the largest cities in the country also showed that the level of adoption of the standard is quite abysmal probably because SMEs in the country has gained very little of any benefits from the introduction of the standard. Aboagye-Okyere \& Agbeibor, (2012) also discovered in their study that, 70\% of the issues that the standard was established to solve, were found to be irrelevant to SMEs which also explains why SMEs are not benefiting greatly from the standard.

\section{The challenges encountered by firms in the implementation of the IFRS for SMEs}

Challenges have become a part of every human endeavor and draws a line between human imaginations and reality in the world. Responses from our respondents have sparked several issues regarding the implementation of the new standard, IFRS for SMEs. However, countries that decided to and have adopted the standard were expected to enjoy maximum benefits with 
very little room for challenges. Most of these countries were driven by high motivating indicators to adopt the standard and therefore expected to experience the impact of these motivating factors on the life of their businesses. It is in this regard that, Marcellan (2009) said that, global recognition, attraction of talented finance people and the easiness in implementing the full IFRS when required were the reasons that necessitated the release of the IFRS for SMEs.

In the same vein, different authors have argued that, the supplementary benefits to a firm implementing the standard, will include qualification to government tenders and bank loans. Based on this assumption, one would expect these SMEs in Madina to attract more business or sales and to find it easier to obtain bank loans, however, responses from IFRSforSMESR9 10, 16, 20 do not support this assumption as they emphatically stated that the adoption of the standard has not added any significant benefit to the firm during and after its implementation with difference in paper works being the only change. To these firms, the level of business activities, such as sales, purchases, ability to secure credit facilities, external investment and the like have seen little or no improvement and this view was also held by Rudzani \& Charles (2016) that most SMEs who have adopted the popular standard, could not clearly identify any improvement that the standard has provided to their businesses.

In the view of IFRSforSMEsR 18“ Our accounting staff were not highly skilled in the standard to support the entity in the implementation processes at the initial stage and I believe is due to the fact that the format we have been using which makes the preparation easy, is far different from that of the IFRS for SMEs and more so, the standard is quiet difficult". Out of the users of the standard in the preparation of their financial statement, IFRSforSMEsR14, IFRSforSMEsR20, in support of the opinion above also believed that, there are some prerequisite skills needed by SMEs such as knowledge and ability to interpret and apply all sections of the standard successfully.

To these firms, their staff do not possess such skills hence implementation of the standard had been a challenge. This challenge was equally realized from a similar study conducted by (Rudzani \& Charles, 2016) in their quest to find the challenges that SMEs in South Africa encounter when implementing the IFRS for SMEs.

Complexity of the IFRS for SMEs is a reason why the respondents under this study argued that they lacked the necessary skills needed to implement the standard. Samugh and Devi (2015) also stated in their findings that, the low patronage of the standard by SMEs is due to its complex nature and the low level of technical knowledge among SMEs. Rudzani and Charles (2016) agreed with this challenge and proposed in their study that the IFRS for SMEs should be reviewed to reduce its level of complexity

"We have only one accountant who is a fresh graduate and can only assist the firm in bookkeeping and other accounting related activities but has very little knowledge of the said standard and therefore we were exposed to huge cost to start the implementation". IFRSforSMEsR13. "The accountant of the firm does not have the requisite skills to implement the standard and as such we had to outsource our accounting function before we could implement the standard" IFRSforSMEsR20. 
SMEs that are not properly organized in general, may incur more cost in operating certain departments fully hence resort to part-time employees and as well as outsourcing most of their functions and this is a reason why they lack professionally qualified staff who are fully employed such similar tasks.

"We did not want to replace our accountant, but we eventually have to train him through seminars, cost to hire a tutor to professionally groom the accountant as well as other IFRS tutorials materials" IFRSforSMEsR12. "When our accountants acquire professional qualifications, their demands becomes too high for a small private company like ours and we cannot continue paying them high salaries simply to keep them".

Cost has become a key challenge in the implementation of the standard. $75 \%$ of our respondents who had adopted the standard all had cost as a similar challenge. It is no surprise that, the researchers have not yet come across studies on challenges of the implementation of the IFRS for SMEs that did not discover cost as one of the pressing challenges of SMEs in the countries that have adopted the standard. Similar studies conducted by, (Rudzani \& Charles, 2016) and Arhin all attested to the fact that cost has been a major challenge when a firm decides to adopt and implement the standard.

"We were made to adopt the standard because it has been made compulsory for all SMEs when registering the business." IFRSforSMEsR13. Some of the respondents also expressed concerns of how the standard was imposed on them. To them, they had to implement the standard against their will. This is as a result of the decision by ICAG to adopt the internationally acclaimed standard for use by all SMEs in Ghana. This observation is however supported by a similar study conducted by Rudzani and Charles (2016) in South Africa that, an appreciable number of its respondents believed they adopted the standard against their will. This raises the question whether the standard should be made optional rather than its current compulsory form?

\section{The roles of regulatory bodies in the successful adoption and implementation of the IFRS for SMEs.}

A parliamentary act established the ICAG to regulate the accountancy profession in Ghana. They are also the accounting standards setter for the country. It is expected that since they adopted the standard to replace the Ghanaian accounting standards, they will have measures put in place to ensure that SMEs in the country are in better positions to adopt and implement the standard successfully. However, when SMEs were asked of their knowledge of any role of regulatory bodies in ensuring that SMEs successfully implement the standard as well as provide continuous support to SMEs as and when old standards are reviewed and new standards are introduced, they stated that, they had no such support from any regulatory body. "I have not been aware of any role of regulatory bodies to help my business or other businesses to operate the IFRS for SMEs" Respondent 18 "I have not been assisted by any regulatory body on how to implement the standard" Respondent 12. This supports the argument by Arhin, Perprem, \& Hulede (2017) that regulatory and professional bodies do not support SMEs to implement IFRS for SMEs successfully". However, some of these SMEs have some expectations that they expect regulatory bodies to organize seminars, training sessions. They also expected that 
regulatory bodies will set up team of professional who will be engaged with the SMEs to know the challenges they face and assisted them to devise ways to solve their challenges.

\section{Conclusion and Recommendations}

Overall, the outcomes of these study give an indication that, the IFRS for SMEs currently is not known by SMEs in the country. This means that, the solutions professed by the standard to SMEs cannot be obtained by SMEs. Access to local credit facilities was the main benefit that the adoption of the IFRS for SMEs has added to businesses in Madina. The findings that, the standard brought no international benefit support the argument that, the IASB's objective of allowing SMEs to access international competitive funds through the implementation of the IFRS for SMEs is a distant objective. The respondents who are challenged by the high cost of implementation and lack of competent staff to use the IFRS for SMEs support the common assumption that there is a shortage of well qualified accountants and other financial management expertise in the country, with the few available charging exorbitant fees. The study also revealed that SMEs expert regulatory bodies to establish policies that will assist SMEs in the implementation process of the standard although currently there is no such effort.

\section{Limitations of the study}

It is important to note that, this study was exploratory in nature and thus subject to several limitations which can be addressed in future research. The first limitation relates to the small number of interviews that might affect the generalization of the findings. The sample was selected from only SMEs in Madina and thus cannot be generalized to all SMEs in the country.

The second restraint of this study relates to the definition of the SME itself. While it is generally accepted that the number of employees could be used as an alternate measure for firm size, expanding the definition to encompass the sales or revenue of the firms may produce different results.

\section{Recommendation for further studies}

The IFRS for SMEs is a broader scope of accounting which cannot be dealt with in its entirety in this study alone. Further studies should be conducted on:

- The relevance of the IFRS for SMEs to Micro entities who form part of the SMEs.

- The suitability of the standard from the perspective of other stakeholders in SME financial reporting such as bankers and tax authorities.

- The usefulness and challenges of the recognition and measurement principles, disclosures and accounting policy options of the standard.

- Studies focusing on entities on the larger end of the IASB's SME definition could also consider whether the IFRS for SMEs would reduce the in-formativeness of the financial statements of these entities or fail to provide guidance on certain pertinent issues. 


\section{References}

Abata, M. (2015). The impacts of the IFRS on financial reporting in Nigeria. global journal of contemporary research in accounting, auditing and business ethics.

Aboagye-Okyere, A., \& Agbeibor, J. (2012). The International Financial Reporting Standards for Small and Medium Sized Entities. Suitability for small businesses in Ghana. Journal of Financial Reporting and Accounting, 190-214. https://doi.org/10.1108/19852511211273723

Aboagye-Okyere, F., \& Agbeibor, J. (2012). International Financial Reporting standards for SMEs. journal of financial reporting and accounting, 190-214. https://doi.org/10.1108/19852511211273723

Aggestam, C. (1999, february 17-19). Towards a global accounting qualification. 16th session of the ISAR group of the UN Palais de nations, Geneva, 805-813. https://doi.org/10.1080/096381899335835

Agyei- Mensah, B. K. (2012). the impact of adopting IAS1 in ghana. the extent of disclosures and their relationship to corporate characteristics. african journal of business management, 10896-10905. https://doi.org/10.5897/AJBM11.1857

Albu, N., \& Albu, C. (2012). Strategies for and implication of the IFRS for SMEs implementation in Emerging Economies. Grenoble: Comptabilities et innovation. https://doi.org/10.1016/j.cpa.2007.12.005

Alp, A., \& Ustundag, S. (2009). Financial reporting transformation: the experienceof Turkey. Critical Perspectives on Accounting, 680-699.

Amoako, G. (2013). accounting practices of smes. a case study of kumasi metropolis in ghana. international journal of business and management, 1833-3850. https://doi.org/10.5539/ijbm.v8n24p73

Amoako, O. K., Marfo, O., G. N., \& gyamfi, O. \&. (2014). accounting records keeping practices of smes in ghana Evidence from sunyani municipality. british journal of economics, finance and management studies, vol 9(1).

Appiah, O., Awunyo-Vitor, D., Mireku, K., \& Ahiagbah, C. (2016). compliance with international financial reporting standards. A case of listed firms in ghana. journal of financial and accounting, 131-156. https://doi.org/10.1108/JFRA-01-2015-0003

Arhin, T., Perprem, a., \& Hulede, A. (2017). the challengies of adoption and implementing ifrs for smes in ghana. a case of smes in the kumasi metropolis. research journal'sjournal of accounting, 1-13.

Ashraf, J., \& Ghani, W. (2005). Accounting development in Pakistan. International journal of accounting, 175-189. https://doi.org/10.1016/j.intacc.2005.01.010

Awal, I. (2017, June 07). 75\% Businesses Fail After 3 Years. Retrieved October 26, 2018, from modernghana.com/news: https:/www.modernghana.com/news/780532/75-businesses-failafter-3-years.html 
Betul, C. (2004). Using Nvivo to analyse qualitaive classroom data on constrativist learning environment. Qualitive Research Graduate, 589-603.

Boachie-Mensah, F., \& Marfo-Yiadom, E. (2005). Enterpreneurship and Small Business Management. Accra: Ghana Universities Press.

Dictionary-Business. (2018). businessdictionary. Retrieved from Research methodology: ww.businessdictionary.com

Dimaggio, P., \& Powell, W. (1991). The new institutionalism and organizational analysis. In P. \&. Dimaggio, The iron cage revisited: institutional isomorphism and collective rationality in organizational fields (pp. 1-38). Chicago: university of Chicago Press.

El-Gazzar, Sawn, Finn, P, \& Jacob, R. (1999). An empirical investigation of multinational firms' compliance with international accounting standards. International journal of accounting, 239-254. https://doi.org/10.1016/S0020-7063(99)00005-9

Epstein, B., \& Jermakowicz, E. K. (2010). Interpretation and Application of International Financial Reporting Standards. New York: John Wiley \& Sons, Incoporation.

Estandardsforum. (2009). International financial reporting standards, Financial standards . Ghana: Financial standards foundation.

Ezejiofor, R., Ezenyirimba, E., \& Olise, M. (2014). The Relevance of Accounting Records in Small Scale. International Journal of Academic Research in Business and Social Sciences, 2222-6990. https://doi.org/10.6007/IJARBSS/v4-i12/1329

Fox, J. (2018, October 26). 95\% of small businesses fail in the first five years - don't let yours be one. Retrieved October 26, 2018, from ghanatalksbusiness.com: https://ghanatalksbusiness.com/95-small-businesses-fail-first-five-years-dont-let-one/

Gordon, L., loeb, M., \& zhu, w. (2012). impacts of IFRS adoption on foreign direct investments. journal of accounting and public policy, 374-398. https://doi.org/10.1016/j.jaccpubpol.2012.06.001

Guler, I., Guillen, M., \& Macpherson, J. (2002). Global competition, institutions, and the diffusion of organizational practices: the international spread of ISO 9000 quality certificates. Administrative science quarterly, 207-232. https://doi.org/10.2307/3094804

Gyasi, A. (2010). Adoption of International Financial Reporting Standards in developing countries- The case of Ghana. Business Economics and Tourism, 74-82.

Hassan, M. (2008). The development of accounting regulations in Egypt, legitimating the international accounting standards. london: Emerald group publishing limited.

Ialin, H., \& Irfan, s. (2010). research on usage and usefulness perception of financial accounting practices in less developed countries. a case of Cambodia. international confernce of precedings and management, 1881-1885.

IASB. (2009). IFRS FOR SMES. IASB. 
IASB. (2018, May 18). Wikipedia. Retrieved from Wikipedia: https://en.wikipedia.org/wiki/International_Financial_Reporting_Standards

International Trade Centre. (2016). SME Competitiveness in Ghana: Allianaces for Action. ITC, 16-27.

Inusah, N. (2017). IFRS Adoption in Ghana: The Dimension of Challenges Firms Ecounter. International Journal of Accounting and Financial Reporting, 2162-3082. https://doi.org/10.5296/ijafr.v7i2.12028

Jalil, M. (2013). Practical guidlines for conducting research. Donor Committee for Enterprise Development.

Jon, Z. (2018, april 23). meaning of sample size. Retrieved from sciencing: http://sciencing.com Judge, W., Li, S., \& Pinsker, R. (2010). National Adoption of International Accounting Standards: An Institutional Perspective. Corporate Governance; An international Review, 161174. https://doi.org/10.1111/j.1467-8683.2010.00798.x

Kilic, U., \& Ataman, B. (2016). Prepardness of the entities for the IFRS for SMEs: an emerging Country case. Journal of Accounting in Emerging Economies, 80-98. https://doi.org/10.1108/JAEE-01-2014-0003

Mandilas, A., Nikolaidis, M., \& Stavros, V. (2015). The adoption of ifrs . The case of Kavala, Greece. Research gate, 409-432.

Marcellan, M. (2009). A guide through IFRS for Small Medium Sized entities. London: RSM International.

Marcoulides, R. (2015). Scale Reliability Evaluation With Heterogeneous Populations. PMC, 875-892. https://doi.org/10.1177/0013164414558587

Maseko, N., \& Manyani, O. (2011). accounting practices of smes in zimbabwe. an investigative study of record keeping for performance measurement. journal of accounting and taxation, 171-181.

Merve, K., Ali, U., \& Basak, A. (2016). preparedness of the entities for the ifrs for smes;an emerging country case. journal of accounting in emerging economies, 156-178. https://doi.org/10.1108/JAEE-01-2014-0003

Murni, M., Mansu, A., \& osman, A. (2011). Proposing a working definition and framework to evaluate islamic website. The International Workshop on Internalisation of Products and Systems (IWIPS 2011).

O’Dell, J. (2008). Private Company Financial Reporting Committee. London: FASB.

obuyhbjh. (n.d.). uygiuhg. rcygvuh.

Olatunji, T. (2013). The Impact Of Accounting System On The Performance Of Small And Medium Scale Enterprises In Nigeria - A Survey Of SME's. international journal of business and management intervention, 13-17. 


\section{Macrothink}

Asian Journal of Finance \& Accounting

ISSN 1946-052X 2019, Vol. 11, No. 1

Pacter, P. (2008). IFRS for Private Entities IFRS for Private Entities. london: IASC Foundation. https://doi.org/10.1057/jdg.2008.24

Pacter, P. (2009). An ifrs for private entities. international journal of disclosure and governance, 4-20. https://doi.org/10.1057/jdg.2008.24

Parboteeah, C., \& Tomoaki, V. \&. (2005). National culture and ethical climates. 459-481.

Peeters, M., Beltyukova, S., \& Martin, B. (2013). Educational Testing and Validity of Conclusions in the Scholarship of Teaching and Learnin. American Journal of Pharmaceutical Education, 180-186. https://doi.org/10.5688/ajpe779186

Polit, D., \& Hungler, B. (1999). NursingResearch Principles and Method. American Journal of Nursing Research, 416-417.

Preface to IFRS No. 2. (2002). Preface to IFRS . London: IASB Foundation.

Preface to IFRSs NO. 15. (2002). Preface to IFRSs. London: IASB Foundation.

Preface to IFRSs NO. 6. (2002). Preface to IFRSs. London: IASB Foundation.

Pricewaterhousecoopers. (2009). ifrs for smes.

Quartey, P., \& Abor, J. (2010). issues in sme development in ghana and south africa. international research journal for finance and economics, 218-228.

Radaelli, C. M. (2000, Dcember 17). Policy Transfer in the European Union: Institutional Isomorphism as a Source of Legitimacy. An international journal of Policy, Administration and Institutions, 25-43. https://doi.org/10.1111/0952-1895.00122

ROSC. (2004). Observance of standards and codes.Accounting and auditing. accra: world bank.

ROSC. (2004). world bank report on the observance of standards and codes.Accounting and auditing. accra.

Rudzani, S., \& Charles, D. (2016). An assessment of the challenges of adopting and implementing IFRSS for. Problems and Perspectives in Management, 212-221. https://doi.org/10.21511/ppm.14(2-1).2016.10

Samugh, H., \& Devi, S. (2015). Implememting IFRS for SMEs:challenges for developing economies. International Journal of Mananagement and Sustainability, 39-59. https://doi.org/10.18488/journal.11/2015.4.3/11.3.39.59

Saunders, M., lewis, P., \& and Thornhill, A. (2003). research methods for business studies.

Scott, H., \& Des, N. (2012). moddelling the accounting information of small business. Accounting and Business research, 143-150.

Scott, R. (1995). Institutions and organization. Thousand Oaks. CA: Sage. 


\section{Macrothink}

Asian Journal of Finance \& Accounting

ISSN 1946-052X 2019, Vol. 11, No. 1

Scott, R. (2004). Institutional theory. In G. Ritzer, Encyclopedia of Social Theory (pp. 408414). Califonia: Sage.

Simmons, K., Hamann, S., Harenski, C., Xiaoping, H., \& Barsalou, L. (2008). FMRI evidence for word association and situated simulation in conceptual processing. Journal of Physiology Paris, 106-119. https://doi.org/10.1016/j.jphysparis.2008.03.014

Sithole, M. (2015). The relevance of International Financial reporting Standard for SMEs in Swarziland. Journal of modern accounting and auditing, 383-402.

Titilayo, D., Folashade, O., \& Ifeoma, O. (2014). International Financial Reporting Standards(IFRS) for SMEs Adoption Process in Nigeria. European Journal of Accounting Auditing and Finance Research, 33-38.

University of the witwatersand. (2018, July 9). Libguides. Retrieved from https://libguide.wits.Za

Uzma, S. H. (2015). Cost benefit analysis of IFRS Adoption:Developed and Emerging Countries. Journal of Financial Reporting and Accounting, 198-229. https://doi.org/10.1108/JFRA-01-2015-0019

Walton. (2011). An Executive Guide to IFRS - Content, Costs and Benefits to Business. Cornwall, United Kingdom: John Wiley \& Sons Inc.

Walton, P. (1992). Differential reporting and the European Community: A suitable case for treatment. European Business Journal, 43-48.

Ward, S. (2018). SME Definition. the balance smb.

wikipedia. (2018, october 14). wikipedia. Retrieved from http://en.m.wikipedia.org

Williams, J., Haka, S., Bettner, M., \& Carcello, J. (2008). Financial and Managerial Accounting. New York: Mc Graw-Hill Irwin.

World Bank. (2017). World Bank SME Statistics. Zimbabue: World Bank Press.

Worldbank. (2004). Report on observance of standards and codes, Ghana. Accra: world bank. https://doi.org/10.1596/25714

Wyk, H. v., \& Rossouw, J. (2009). "IFRS for SMEs in South Africa: a giant leap for accounting, but too big for smaller entities in general. meditari accounting research, 99-116. https://doi.org/10.1108/10222529200900007

Zegal, D., yosra, s., \& Sondra, c. (2011). an analysis of mandatoryadoption of ias/ifrs on earnings management. international accounting, auditing and taxation, 61-72. https://doi.org/10.1016/j.intaccaudtax.2011.06.001 